\title{
Identification and quantification of two species of oyster larvae using real-time PCR $^{\star}$
}

\author{
Ana SÁNCHEZ ${ }^{1, a}$, Javier QUINTEIRO ${ }^{2}$, Manuel REY-MÉNDEZ² ${ }^{2}$ Ricardo ISAAC PEREZ-MARTín ${ }^{1}$ \\ and Carmen González SOTELO ${ }^{1}$ \\ ${ }^{1}$ Instituto de Investigaciones Marinas, Consejo Superior de Investigaciones Científicas (CSIC), Eduardo Cabello 6, \\ Vigo 36208 Pontevedra, Spain \\ 2 Laboratorio de Sistemática Molecular (Unidad Asociada al CSIC), Departamento de Bioquímica y Biología Molecular, CIBUS, \\ Campus Vida, Universidad de Santiago de Compostela, Santiago de Compostela 15782 A Coruña, Spain
}

Received 1st August 2014; Accepted 2 December 2014

\begin{abstract}
A real-time polymerase chain reaction (PCR) assay was developed for the identification and quantification of two oyster species: Ostrea edulis and Crassostrea gigas. Two sets of primers and TaqMan-MGB probes were designed, based on partial sequences of the 16S rRNA gene. An amplification positive control system was also located in the 18S rRNA gene sequences. Closely related species of oysters and other bivalves, known to co-occur with the target species in European waters, were used to test the assay for cross-reactivity. The assay designed was specific for the target species and no signal or no significant signal was detected for all non-target species tested. The high sensitivity of this method was demonstrated since it is possible to detect just one larva (150-200 $\mu \mathrm{m}$ size) of each species even when it is present with others. Furthermore, this assay provided an acceptable quantification of the number of spiked larvae (1, 10 and 100 larvae) in plankton samples employing a standard curve for larvae.
\end{abstract}

Keywords: Real-time PCR / Oyster larvae identification / Species identification / 16S rRNA

\section{Introduction}

The northwest of Spain (Galicia) is one of the regions in the world where the cultivation of bivalves has gained significant importance, due to its suitable environmental and geographical conditions which provide high yields in this area (Figueiras et al. 2002). The flat oyster, Ostrea edulis Linnaeus 1758 , is an autochthonous species in this area. Nowadays, natural production of this species is almost symbolic due to its high susceptibility to Bonamia parasitosis (Iglesias et al. 2005). The high mortality rates of $O$. edulis led to the consequent introduction of the Pacific oyster, Crassostrea gigas (Thunberg 1793), mainly from France (Iglesias et al. 2005; Mirella da Silva et al. 2005), which is now the main oyster cultivated in Galicia. This signifies that in the same area it is possible that both species co-occur.

Identification of plankton larvae, particularly bivalves species, is a difficult task, mainly due to their small size $(<500 \mu \mathrm{m})$ and the great morphological similarity among the different species in the early stages of the biological cycle (Garland and Zimmer 2002). The ability to differentiate between bivalve species in their early larval phases allows for a

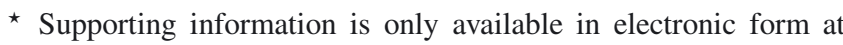
www.alr-journal.org.

a Corresponding author: asanchez@iim.csic.es
}

more comprehensive knowledge of larval dispersal pathways, population connectivity and gene flow. Such knowledge would provide the information needed for proper fisheries and management of wild and cultured marine resources in regions like Galicia, or countries where production of bivalve molluscs is an important economic resource.

Classical methodology for identifying bivalve larvae relies on observation of morphological characters by optical microscopy. Such methodology is typically time consuming and often requires taxonomic expertise as larval phases of bivalves often do not show clear morphological differences. Therefore, due to time constraints, the number of samples which can be analyzed by this procedure are generally low and this hampers monitoring works or studies which require high sampling.

Immunological techniques currently offer a method for identifying plankton larvae. Some authors have successfully applied polyclonal antibodies for larval identification in plankton samples (Paugam et al. 2000; Paugam et al. 2003) but cross-reactions with non-target species. The use of monoclonal antibodies is an alternative method which has been successfully applied in the identification of mussel species (Lorenzo-Abalde et al. 2005; Pérez et al. 2009).

There are other recent methods of species identification based on fluorescent in situ hybridization with DNA probes, FISH-CS (Le Goff-Vitry et al. 2007; Henzler et al. 2010) and 
image analysis (Thompson et al. 2012; Goodwin et al. 2014). In situ hybridization has been effective in zooplankton larvae identification but some aspects, such as autofluorescence, need improvement since they could compromise the effectiveness of labeling techniques by yielding false positives. Although image analysis methods like ShellBi attain high accuracy in the identification of larvae reared in the hatchery, the effect of different growth conditions (temperature and salinity) on shell formation between larvae reared in the hatchery and in the field cause a significant decrease in accuracy $(30 \%$ if larvae are not grown in similar conditions to those used in the larvae classification). Therefore, improvements in image analysis are needed for application to field samples.

Real-time PCR technique (RT-PCR) has emerged as a powerful and rapid tool for species identification. A number of other nucleic acid amplification methods have also been developed, including: species-specific oligonucleotide probes for shellfish larvae identification (Bell and Grassle 1998); RFLP analysis (Toro 1998; Hosoi et al. 2004; Wang et al. 2006); RAPDs (André et al. 1999); multiplexed species-specific PCR (Hare et al. 2000; Bendezu et al. 2005) and nested PCR (Patil et al. 2005). However, none of these has so far been implemented to the same extent as RT-PCR due to its highly sensitive and rapid quantitative detection ability.

In real time PCR technique fluorescence dyes or probes are introduced into the reaction allowing the PCR product formed during the amplification process to be visualized by monitoring the fluorescence signal emitted. There are two types of RT-PCR analysis depending on the fluorescence source. The simplest type involves the use of intercalating dyes such as SYBR Green. These molecules bind to double-strand DNA, producing an increase in fluorescence which correlates with the amount of dsDNA present. The major drawback is that any double stranded product, including unspecific products or primer-dimers, will be detected and false positives can thus occur. The second type is a more specific method for detecting the accumulation of an amplicon because this involves the use of fluorescent probes that are designed to be complementary to a target sequence within the amplicon. There are several types of probes, such as molecular beacons, scorpions and TaqMan probes (hydrolysis probes). The most commonly used, TaqMan probes, are labelled with reporter and quencher fluorophores in the $5^{\prime}$ and $3^{\prime}$ ends, respectively. Reporter fluorescence is reduced by the quencher as long as the probe is intact, regardless of whether it is attached to its target. When Taq polymerase with a $5^{\prime}$ nuclease activity begins to add nucleotides and hydrolyzes the probe attached to the template DNA, the quencher is separated from the reporter, thereby enabling the emission of fluorescence which is then registered and analyzed by the real time PCR software. The most common method used to analyse the experimental data is the Threshold Cycle Method whereby a fluorescence threshold value, within the exponential phase of the amplification curve, is selected. The PCR cycle at which the sample curve exceeds this fluorescence threshold is the $\mathrm{Ct}$ value. This data is used to compare all samples.

Real-time PCR has been successfully used for identifying and quantifying phytoplankton species (Hosoi-Tanabe and Sako 2005), shellfish (Dias et al. 2008) and other marine invertebrate larvae (Vadopalas et al. 2006; Pan et al. 2008; Wight et al. 2009; Smith et al. 2012). Furthermore, in a previous study (Quinteiro et al. 2011), a real-time PCR assay was used for the identification and quantification of Manila clam larvae (Ruditapes philippinarum) and successful results were obtained in terms of specificity and sensitivity. Taking into account this background work, the development of a reliable real-time PCR assay for efficient and specific identification and quantification of $O$. edulis and C. gigas larvae in plankton samples is proposed.

\section{Materials and methods}

\subsection{Samples collection}

Adult samples of $C$. gigas, C. angulata and O. edulis were collected from several locations as show in Table 1. Further specimens belonging to other adult bivalve species, 99 specimens from 41 species, were obtained from local markets, collected from several locations on the Galicia coast and donated by other research institutions and universities (Table 1).

Plankton samples were collected by CETMAR (Technological Centre of the Sea, Vigo, Spain) from different locations along the northwest coast of Spain in 2009 and 2010. Sampling was done using double oblique tows equipped with a $40-\mu \mathrm{m}$ mesh at a depth of $10 \mathrm{~m}$. The samples (400-500 L) were filtered again through $40-\mu \mathrm{m}$ mesh upon return to the laboratory and any retained material was suspended in $20 \mathrm{ml}$ of sterile seawater. Bivalve larvae were isolated using sugar gradient centrifugation (Pérez et al. 2009), suspended in seawater and stored at $-20{ }^{\circ} \mathrm{C}$.

C. gigas and $O$. edulis larvae (150-200 $\mu \mathrm{m}$ size) were obtained from single-species experimental cultures at the CIMA-Corón (Center for Marine Research). These larvae were counted under binocular lenses (NIKON SMZ-2T) and transferred by pipette to $1.5-\mathrm{ml}$ microfuge tubes with $20 \mu \mathrm{l}$ of ethanol $(33 \%)$. Standard samples containing larvae from 1 to $128(1,2,4,8,16,32,64$ and 128) of each species were used to generate standard quantification curves. Three samples consisting of 1, 10 and 100 cultured larvae of $C$. gigas and O. edulis were further isolated and used to spike the CETMAR plankton samples that contained around 250 larvae of other bivalve species, mostly Mytilus galloprovincialis.

\subsection{DNA extraction}

DNA from most adult bivalve samples (with the exception of $C$. gigas) was extracted from $0.2 \mathrm{~g}$ of adductor muscle, mantle or foot tissues after overnight digestion in a thermo shaker at $56{ }^{\circ} \mathrm{C}$ with $860 \mu \mathrm{l}$ of lysis buffer $(1 \%$ SDS, $150 \mathrm{mM} \mathrm{NaCl}$, $2 \mathrm{mM}$ EDTA, $10 \mathrm{mM}$ Tris- $\mathrm{HCl} \mathrm{pH} 8), 100 \mu \mathrm{l}$ of $5 \mathrm{M}$ guanidium thiocyanate and $40 \mu \mathrm{l}$ of proteinase $\mathrm{K}\left(\geq 20 \mathrm{Unit}^{-1}\right)$. After $3 \mathrm{~h}$ of digestion, extra proteinase $\mathrm{K}(40 \mu \mathrm{l})$ was added to the solution and it was left overnight. DNA was then isolated using the Wizard DNA Clean-Up System kit (Promega) following manufacturer's instructions. Crassostrea gigas adult samples were processed with the EZNA Mollusk kit (OMEGA bio-tek). A piece of $0.2 \mathrm{~g}$ of adductor muscle was digested 
Table 1. Tissue samples from bivalve species used for the study. IFREMER, France. XG: Consellería do Mar, Xunta de Galicia (Spain).

\begin{tabular}{|c|c|c|c|}
\hline Species & Key & $N$ & Source \\
\hline \multicolumn{4}{|l|}{ Order Mytiloida } \\
\hline Mytilus edulis & MEDU & 2 & \multirow{3}{*}{ This work } \\
\hline Mytilus galloprovincialis & MGAL & 1 & \\
\hline Xenostrobus securis & XSEC & 1 & \\
\hline \multicolumn{4}{|l|}{ Order Ostreoida } \\
\hline Crassostrea angulata & CANG & 10 & This work \\
\hline Crassostrea gasar & CGAS & 1 & IFREMER \\
\hline Crassostrea gigas & CGIG & 19 & This work \\
\hline Crassostrea hongkongensis & $\mathrm{CHON}$ & 1 & $\begin{array}{l}\text { Applied Marine Biology Lab, South China } \\
\text { Sea Institute of Oceanology (China) }\end{array}$ \\
\hline Crassostrea sikamea & CSIK & 1 & $\begin{array}{l}\text { Tohoku National Fisheries Research Institute } \\
\text { (Japan) }\end{array}$ \\
\hline Crassostrea virginica & CVIR & 1 & University of Georgia (USA) \\
\hline Ostrea angasi & OANG & 1 & IFREMER \\
\hline Ostrea chilensis & $\mathrm{OCHI}$ & 1 & Southern University of Chile \\
\hline Ostrea conchaphila & OCON & 1 & IFREMER \\
\hline Ostrea edulis & OEDU & 31 & This work \\
\hline Ostrea lurida & OLUR & 1 & Oregon State University (USA) \\
\hline Ostrea stentina & OSTE & 1 & IFREMER \\
\hline \multicolumn{4}{|l|}{ Order Pectinoieda } \\
\hline Aequipecten opercularis & AOPE & 1 & This work \\
\hline Chlamys varia & CVAR & 1 & $\mathrm{XG}$ \\
\hline Limaria hians & LHIA & 1 & This work \\
\hline Pecten maximus & PMAX & 1 & $\mathrm{XG}$ \\
\hline \multicolumn{4}{|l|}{ Order Veneroida } \\
\hline Acanthocardia echinata & $\mathrm{AECH}$ & 1 & This work \\
\hline Callista chione & $\mathrm{CCHI}$ & 1 & This work \\
\hline Cerastoderma edule & CEDU & 1 & $\mathrm{XG}$ \\
\hline Clausinela fasciata & CFAS & 1 & This work \\
\hline Dreissena polymorpha & DPOL & 1 & \multirow{9}{*}{$X G$} \\
\hline Donax trunculus & DTRU & 1 & \\
\hline Ensis ensis & EENS & 1 & \\
\hline Ensis silicua & ESIL & 1 & \\
\hline Gari depressa & GDEP & 1 & \\
\hline Glycimeris pilosa & GPIL & 1 & \\
\hline Laevicardium crassum & LCRA & 1 & \\
\hline Ruditapes decussatus & RDEC & 1 & \\
\hline Ruditapes philippinarum & RPHI & 1 & \\
\hline Scrobicularia plana & SPLA & 1 & \multirow{3}{*}{ This work } \\
\hline Solen marginatus & SMAR & 1 & \\
\hline Spisula solida & SSOL & 1 & \\
\hline Venerupis pullastra & VPUL & 1 & $\overline{X G}$ \\
\hline Venerupis rhomboideus & VRHO & 1 & $\mathrm{XG}$ \\
\hline Venerupis aurea & VAUR & 1 & \multirow{4}{*}{ This work } \\
\hline Venus casina & VCAS & 1 & \\
\hline Venus gallina & VGAL & 1 & \\
\hline Venus verrucosa & VVER & 1 & \\
\hline
\end{tabular}

in $350 \mu \mathrm{l}$ of ML1 buffer supplied with the Kit and $40 \mu \mathrm{l}$ of proteinase $\mathrm{K}\left(\geq 20 \mathrm{Unit}_{\mathrm{mg}}^{-1}\right)$. After $3 \mathrm{~h}$ of digestion, another $40 \mu \mathrm{l}$ of proteinase $\mathrm{K}$ was added and it was left overnight. DNA was then isolated following manufacturer's instructions.

DNA extracts from adult samples were quantified by UVspectrometry at $260 \mathrm{~nm}$ and by Quant-iT PicoGreen dsDNA Assay Kit (Invitrogen) for dsDNA quantification with a VersaFluor Fluorometer (Bio-Rad). DNA concentration

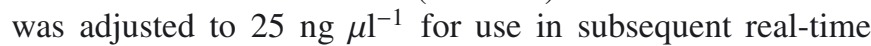
$\mathrm{PCR}$ reactions.
Samples of cultured $C$. gigas and $O$. edulis larvae were washed in sterile Milli-Q water for $20 \mathrm{~min}$ at room temperature to eliminate the ethanol, then the larvae were isolated by removing the supernatant liquid after centrifugation at $10000 \mathrm{~g}, 1 \mathrm{~min}$. DNA extraction from larvae was carried out using EZNA Mollusc kit (OMEGA bio-tek) following manufacturer's instructions. Finally, DNA was eluted in $50 \mu \mathrm{l}$ of elution buffer.

The quality of DNA extracts, from adult and cultured samples, was evaluated by the UV ratio $260 \mathrm{~nm} / 280 \mathrm{~nm}$, obtaining 
values between 1.8 and 2 for adult samples and between 1.4 and 1.9 for cultivated larvae.

\subsection{DNA amplification and sequencing}

The universal primers 16Sa: 5'CGCCTGTTTAACAAAAACAT3' and 16Sb: 5'ACGTGATCTGAGTTCAGACCGG3' (Palumbi et al. 1991) were used to amplify a fragment of approximately $490 \mathrm{bp}$ of the mitochondrial $16 \mathrm{~S}$ rRNA gene for the $C$. gigas, $C$. angulata and $O$. edulis species and another 18 bivalve species (Table 2). PCR was performed on a final volume of $25 \mu$ l using PuReTaq ${ }^{\text {TM }}$ Ready-To-Go ${ }^{\text {TM }}$ PCR beads (GE Healthcare), $2.4 \mu \mathrm{M}$ of each primer, water and DNA. Amplification conditions consisted of an incubation step of $94^{\circ} \mathrm{C}$ for $3 \mathrm{~min}$, followed by 35 cycles of $94{ }^{\circ} \mathrm{C}$ for $40 \mathrm{~s}, 50{ }^{\circ} \mathrm{C}$ for $40 \mathrm{~s}, 72{ }^{\circ} \mathrm{C}$ for $40 \mathrm{~s}$ and a final extension step of $72{ }^{\circ} \mathrm{C}$ for $7 \mathrm{~min}$.

PCR products were treated with $3 \mu \mathrm{l}$ ExoSAP-IT (Ammersham Biosciences) for deactivating dNTPs and hydrolysing single strand DNA in a two step incubation, first at $37{ }^{\circ} \mathrm{C}$ for $30 \mathrm{~min}$ and then at $80{ }^{\circ} \mathrm{C}$ for another $15 \mathrm{~min}$. Sequencing reactions were prepared with the ExoSAP-IT treated PCR products and Big Dye (Applied Biosystems) following manufacturer's instructions. Sequencing reactions consisted of an incubation step of $3 \mathrm{~min}$ at $94{ }^{\circ} \mathrm{C}$, followed by 25 cycles of $10 \mathrm{~s}$ at $96{ }^{\circ} \mathrm{C}, 5 \mathrm{~s}$ at $50{ }^{\circ} \mathrm{C}$ and $4 \mathrm{~min}$ at $72{ }^{\circ} \mathrm{C}$. Products were purified using a standard ethanol precipitation, and the pellet obtained stored at $-20{ }^{\circ} \mathrm{C}$. Sequencing was carried out in an ABI PRISM 310 DNA Sequencer (Applied Biosystems). The resulting sequences were analysed using BIOEDIT (Hall 1999) software and then aligned with other sequences available from Genbank (Table 2) using CLUSTAL (Thompson et al. 1997) software.

\subsection{Probe and primers design}

Two sets of primers and TaqMan-MGB probes were designed for $C$. gigas and $O$. edulis based on the alignment of 16S rRNA gene sequences from 33 bivalve species (Table 2) using Primer Express (version 2.0) software (Applied Biosystems) and following the standard parameters. The specificity of primers and probes were evaluated via BLAST (Johnson et al. 2008). A positive control system for bivalve taxa was also designed in the 18S rRNA gene sequences from the Genbank (Table 2) to discard possible false negatives for nontarget species with the oyster specific systems. The $5^{\prime}$ end of the CGIG/ANG16S_P, OEDU16S_P and BIV18S_P probes were labelled with the fluorescent reporter dyes VIC, FAM and NED respectively.

\subsection{Real-time PCR conditions}

All real-time PCR reactions were performed in a total volume of $20 \mu \mathrm{l}$ consisting of $10 \mu \mathrm{l}$ of TaqMan Fast Universal PCR Master Mix no UNG Amperase (2X), $1 \mu$ l of each primer and probe with a final concentration as described in Table 3, water and $2 \mu \mathrm{l}$ of DNA (25 ng $\mu \mathrm{l}^{-1}$ ) for inclusivity (target species) and exclusivity (non-target species) assays; for larvae quantification assays $2 \mu \mathrm{l}$ of DNA from each extract sample were added. Reactions were conducted in triplicate on an
ABI 7500 Fast (Applied Biosystems) real-time PCR machine at $95{ }^{\circ} \mathrm{C}$ for 10 min followed by 40 cycles of $95{ }^{\circ} \mathrm{C}$ for $15 \mathrm{~s}$ and $60{ }^{\circ} \mathrm{C}$ for $1 \mathrm{~min}$. In all real-time PCR assays three non target control (NTC) wells were included to discard false positives due to contamination. The average $\mathrm{Ct}$ value, calculated for each target species, C. gigas, C. angulata and O. edulis (inclusivity assay) was compared with that of all non-target species (exclusivity assay), using a normal distribution $t$-test with different variances (Yuan et al. 2006). The confidence interval ( $\alpha=0.05$ ) was calculated for the average $\mathrm{Ct}$ value of target and non target species.

\section{Results}

\subsection{DNA sequencing and Real time PCR system design}

The mitochondrial 16S rRNA region, flanked by the $16 \mathrm{Sa}$ and $16 \mathrm{Sb}$ primers, was successfully amplified and sequenced for several bivalve species (Table 2). All data obtained in the present work, together with sequences available on GenBank, were used for the design of a specific real time PCR system for $C$. gigas and $O$. edulis species.

The alignment of $16 \mathrm{~S}$ rRNA sequences of the bivalve species listed in Table 2 point to the existence of many interspecific nucleotide differences between the group composed of the O.edulis, C. gigas and C. angulata sequences and the rest of bivalves sequences used in the alignment (Table 4 and Table S1, online-only material). No inter-specific nucleotide differences were found between the $C$. gigas and $C$. angulata sequences in this region. The absence of inter-specific variability in these two latter species confirms observations from previous studies about the close phylogenetic relationship that exists between these two taxa (Boudry et al. 2003; Reece et al. 2008). Consequently, one system was designed for Ostrea edulis and another for the closely related C. gigas and $C$. angulata. The high inter-specific variability between $O$. edulis and C. gigas/C. angulata sequences with all other bivalve sequences permits the location of potential target sites for designing a real-time PCR system for both groups. Only a few of such potential sites were selected, specifically those that permitted location of specific real-time PCR systems with an adequate score for design parameters (primers and probes melting temperature, GC content, amplicon length, nucleotide composition and secondary structure) included in the Primer Express software. The alignment of the 18S rRNA sequences are used for the design of the positive control system for bivalve taxa (Table S2). No intra-specific variability affecting specificity was detected in any of the systems; this allows identifications without the incidence of false negative results. The sequences of the primers and probes of each of the systems developed are shown (Table 3).

\subsection{Real-time PCR setup}

The optimal concentration of primers and probes was determined experimentally for each system by taking into account combinations of primers and probe that produced the 
Table 2. Sequences used to design the BIV_18S, CGIG/ANG_16S and OEDU_16S systems. GenBank accession numbers in bold letters correspond to sequences obtained during this work. V: Veneroida, P: Pectinoida, O: Ostreoida, M: Mytiloida.

\begin{tabular}{|c|c|c|c|c|}
\hline Species & Order & Key & $\begin{array}{l}\text { Accession number } \\
\text { 18S rRNA sequences }\end{array}$ & $\begin{array}{l}\text { Accession number } \\
\text { 16S rRNA sequences }\end{array}$ \\
\hline Acanthocardia echinata & Veneroida & $\mathrm{AECH}$ & & JF808174 \\
\hline Acanthocardia tuberculata & V & ATUB & AM774522 & \\
\hline Aequipecten opercularis & Pectinoida & AOPE & & JF808175 \\
\hline Anomia ephippium & $\mathrm{P}$ & AEPH & AF120535 & \\
\hline Callista chione & $\mathrm{V}$ & $\mathrm{CCHI}$ & AJ007613 & AJ548772 \\
\hline Cardites antiquata & $\mathrm{V}$ & CAUT & AF120550 & \\
\hline Cerastoderma edule & $\mathrm{V}$ & CEDU & AM774520 & JF808177 \\
\hline Chamelea striatula & $\mathrm{V}$ & CSTR & DQ279943 & \\
\hline Chlamys hastata & $\mathrm{P}$ & CHAS & L49049 & \\
\hline Chlamys islandica & $\mathrm{P}$ & CISL & L11232 & \\
\hline Chlamys varia & $\mathrm{P}$ & CVAR & & AJ586481 \\
\hline Clausinela fasciata & V & CFAS & & JF808178 \\
\hline Crassostrea angulata & Ostreoida & CANG & & JF808176 \\
\hline Crassostrea gasar & $\mathrm{O}$ & CGAS & & JF808179 \\
\hline Crassostrea gigas & $\mathrm{O}$ & CGIG & AB064942 & JF808180 \\
\hline Crassostrea hongkongensis & $\mathrm{O}$ & $\mathrm{CHON}$ & & JF808181 \\
\hline Crassostrea sikamea & $\mathrm{O}$ & CSIK & & JF808182 \\
\hline Crassostrea virginica & $\mathrm{O}$ & CVIR & X60315 & JF808183 \\
\hline Donax trunculus & $\mathrm{V}$ & DTRU & & EF417553 \\
\hline Dosinia corrugata & $\mathrm{V}$ & DCOR & EF426290 & \\
\hline Dosinia exoleta & $\mathrm{V}$ & DEXO & & JF808184 \\
\hline Ensis ensis & $\mathrm{V}$ & EENS & AF120555 & AJ548775 \\
\hline Ensis siliqua & $\mathrm{V}$ & ESIL & & AJ586470 \\
\hline Eucrassatella cumingii & $\mathrm{V}$ & ECUM & AM774479 & \\
\hline Gari elongata & $\mathrm{V}$ & GELO & AM774532 & \\
\hline Glycymeris insubrica & Arcoida & GINS & AF207647 & \\
\hline Limaria hians & Limoida & LHIA & & JF808185 \\
\hline Lutraria lutraria & V & LLUT & AM774553 & \\
\hline Mytilus edulis & Mytiloida & MEDU & AY527062 & NC_006161 \\
\hline Mytilus galloprovincialis & M & MGAL & L33451 & NC_006886 \\
\hline Nucula sulcata & Nuculoida & NSUL & DQ279937 & \\
\hline Ostrea chilensis & $\mathrm{O}$ & $\mathrm{OCHI}$ & & JF808186 \\
\hline Ostrea edulis & $\mathrm{O}$ & OEDU & L49052 & JF808187 \\
\hline Ostrea lurida & $\mathrm{O}$ & OLUR & & JF808188 \\
\hline Ostrea stentina & $\mathrm{O}$ & OSTE & & JF808179 \\
\hline Panopea abrupta & Myoida & PABR & AM774514 & \\
\hline Pecten maximus & $\mathrm{P}$ & PMAX & L49053 & EU379454 \\
\hline Pharus legumen & V & PLEG & AM774510 & \\
\hline Pholas dactylus & Myoida & PDAC & AY070122 & \\
\hline Ruditapes decussatus & V & RDEC & & AJ294949/JF808190 \\
\hline Ruditapes philippinarum & $\mathrm{V}$ & RPHI & AM774568 & \\
\hline Solen marginatus & $\mathrm{V}$ & SMAR & & AJ586473 \\
\hline Solen vaginoides & $\mathrm{V}$ & SVAG & AM774507 & \\
\hline Spisula solida & $\mathrm{V}$ & SSOL & L11266 & JF808191 \\
\hline Venerupis aurea & V & VAUR & & AJ294950 \\
\hline Venerupis pullastra & $\mathrm{V}$ & VPUL & & AJ417845 \\
\hline Venerupis rhomboideus & $\mathrm{V}$ & VRHO & & AJ417848 \\
\hline Venerupis saxatilis & $\mathrm{V}$ & VSAX & AM774571 & \\
\hline Venus casina & $\mathrm{V}$ & VCAS & & JF808192 \\
\hline Venus gallina & $\mathrm{V}$ & VGAL & & JF808193 \\
\hline Venus verrucosa & V & VVER & AJ007614 & AJ294947 \\
\hline
\end{tabular}


Table 3. Primers and TaqMan-MGB probe sequences.

\begin{tabular}{lcccc}
\hline TaqMan System & Primer/Probe & Primer Sequence 5' $\rightarrow 3^{\prime}$ & $\begin{array}{c}\text { Amplicon } \\
\text { length } \\
\text { (bp) }\end{array}$ & $\begin{array}{c}\text { Primer and } \\
\text { Probe } \\
\text { concentration } \\
\text { (nM) }\end{array}$ \\
\hline \multirow{2}{*}{ CGIG/ANG 16S } & CGIG/ANG16S_F & GGGCGCCTAGAAAGCAAGT & 300 \\
& CGIG/ANG16S_R & ATCGGGTCAAATCCGGAAAG & 62 & 300 \\
& CGIG/ANG16S_P & VIC-AACCTTTCTGAATAACTAAC-MGB & 200 \\
OEDU 16S & OEDU16S_F & GGCGCCCCACCTAAAAAT & 62 & 900 \\
& OEDU16S_R & AGACCCCGTGCAACTTTAAAG & 62 & 225 \\
Positive control & OEDU16S_P & FAM- TGAAACTCCTAAACAAGTTG-MGB & 300 \\
& BIV_18S_F & AGCCACACGAGATTGAGCAAT & & 900 \\
\hline
\end{tabular}

lowest $\mathrm{Ct}$ value and the highest final fluorescence value. Such concentrations were used to carry out all assays (Table 3 ).

Real-time PCR efficiency was assessed through seven (CGIG/ANG_16S and BIV_18S) and six (OEDU_16S) 10fold DNA dilutions starting at $50 \mathrm{ng}$. Efficiency curves showed a slope of $-3.34,-3.41$ and -3.35 for CGIG/ANG_16S, OEDU_16S and BIV_18S, respectively. Efficiency of the systems, calculated as $E=\left[10^{(-1 / \text { slope })}-1\right] \times 100$, was found to be $99 \%, 96 \%, 99 \%$ for CGIG/ANG_16S, OEDU_16S and BIV_18S, respectively. Values very close to $100 \%$ efficiency for which the DNA amount in each PCR cycle $(n)$ is twice the amount of the previous cycle $(n-1)$, supporting the correct guidelines for real time PCR assays (Chemistry Guide, Applied Biosystems 2005).

\subsection{Specificity}

The CGIG/ANG_16S and OEDU_16S systems were tested for specificity and cross-reactivity with the bivalve species listed in Table 5. The CGIG/ANG_16S system, which amplifies a $62 \mathrm{bp}$ fragment of the mitochondrial 16S rRNA gene, presents an average $\mathrm{Ct}$ value of $17.37 \pm 0.27$ for all $C$. angulata and $C$. gigas specimens used in the study, while no amplification or no significant signal was obtained from other bivalve species in the cross-reactivity analysis, including O. edulis, as can be seen in Table 5 and Figure 1 ( $\mathrm{Ct}$ average of $39.49 \pm 0.36$ from 42 non-C. gigas/C. angulata specimens).

Similar results were obtained for the OEDU_16S system, for which the $O$. edulis samples gave an average $\mathrm{Ct}$ value of $17.79 \pm 0.21$ with no amplification or no significant signal obtained for most bivalve species in the cross-reactivity analysis, with the exception of $O$. angasi which presents a $\mathrm{Ct}$ value similar to that of $O$. edulis. Some research articles, including Jozefowicz and Ó Foighil (1998), Kenchington et al. (2002) and Hurwood et al. (2005) consider these two taxa as the same species. Following the suggestions in these papers, and based on the identical sequence shown by the two species in the 16S rRNA alignment (Table S1), Ct of O. angasi will be not included in the calculation of non target species $\mathrm{Ct}$ average $(37.90 \pm 2.59$ for 43 non $O$. edulis).

The species used in the cross-reactivity test for the oyster specific systems were also tested with the bivalve, BIV_18S

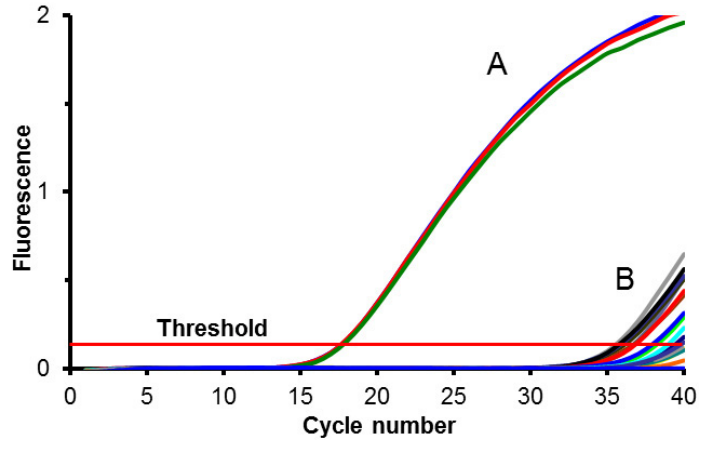

Fig. 1. Graphic representation of the cross-reaction assay to Crassostrea gigas/C. angulata, CGIG/ANG_16S system. A: Amplification pattern for target species. B: Amplification pattern for nontarget species.

positive control system. They showed a positive amplification in all cases (Table 5) with a Ct average of 16.16 \pm 0.97 .

There is a statistically significant difference between the $\mathrm{Ct}$ value obtained for target species and that for the rest of the analyzed non target species $(p<0.001)$ for both systems.

\subsection{Identification and quantification of oyster larvae}

Standard quantification curves were established using DNA isolated from cultured larvae in order to investigate the potential of the CGIG/ANG_16S and OEDU_16S systems for quantification. The standard quantification curves were obtained for samples of 1 to 128 C. gigas and O. edulis larvae (Fig. 2). Detection as low as one single larva was possible with both systems. The potential for $C$. gigas and $O$. edulis larvae quantification from plankton samples was also tested. In order to do this, plankton samples were spiked with 1,10 and 100 larvae of $C$. gigas and $O$. edulis. These were then homogenized and DNA extracted as described in the Materials and Methods section. The number of spiked target larvae was determined by extrapolation from each standard curve. Real and estimated numbers of larvae are highly correlated (Fig. 3). 


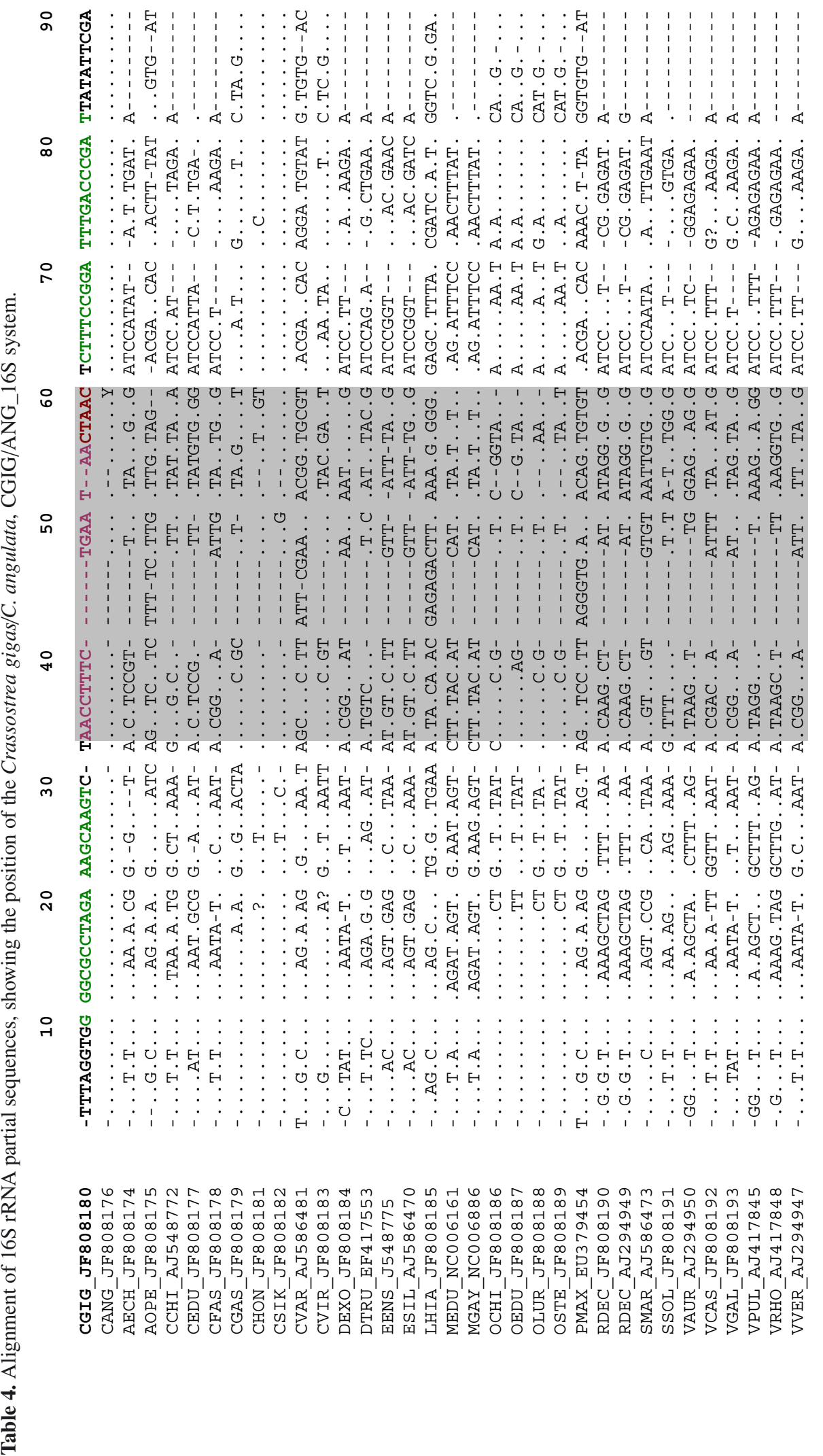


Table 5. Results of cross-reaction assays for CGIG/ANG_16S, OEDU_16S and BIV_18S systems. Average Ct value \pm SD for three replicates. Average $\mathrm{Ct}$ value \pm confidence interval $(\alpha=0.05)$ for oyster specific systems in bold letters. Ct value of 40 means no amplification.

\begin{tabular}{|c|c|c|c|c|}
\hline Species & Sample & CGIG/ANG_16S & OEDU_16S & BIV_18S \\
\hline Crassostrea angulata & CANG 1 & & $33.45 \pm 0.24$ & $14.85 \pm 0.11$ \\
\hline Crassostrea angulata & CANG 2 & & $31.40 \pm 0.38$ & \\
\hline Crassostrea angulata & CANG 3 & & $29.23 \pm 0.01$ & \\
\hline Crassostrea gigas & CGIG 1 & $17.37 \pm 0.27$ & $39.77 \pm 0.40$ & $14.34 \pm 0.03$ \\
\hline Crassostrea gigas & CGIG 2 & & 40 & \\
\hline Crassostrea gigas & CGIG 3 & & $36.63 \pm 0.82$ & \\
\hline Crassostrea hongkongensis & $\mathrm{CHON}$ & 40 & 40 & $16.05 \pm 0.13$ \\
\hline Crassostrea sikamea & CSIK & $39.31 \pm 0.43$ & 40 & $14.50 \pm 0.12$ \\
\hline Crassostrea virginica & CVIR & 40 & 40 & $14.81 \pm 0.03$ \\
\hline Ostrea edulis & OEDU 1 & 40 & & $13.22 \pm 0.03$ \\
\hline Ostrea edulis & OEDU 2 & $36.45 \pm 1.37$ & $17.79 \pm 0.21$ & \\
\hline Ostrea edulis & OEDU 3 & 40 & & \\
\hline Ostrea chilensis & OCHI & 40 & 40 & $13.99 \pm 0.09$ \\
\hline Ostrea stentina & OSTE & 40 & 40 & $15.05 \pm 0.08$ \\
\hline Ostrea angasi & OANG & 40 & $18.86 \pm 0.18$ & $15.70 \pm 0.03$ \\
\hline Crassostrea gasar & CGAS & 40 & $37.26 \pm 0.66$ & $14.12 \pm 0.04$ \\
\hline Ostrea conchaphila & OCON & 40 & 40 & $14.57 \pm 0.04$ \\
\hline Mytilus edulis & MEDU & $36.47 \pm 1.03$ & $35.27 \pm 1.08$ & $13.66 \pm 0.08$ \\
\hline Mytilus galloprovincialis & MGAL & $36.45 \pm 0.86$ & $35.64 \pm 0.62$ & $13.83 \pm 0.04$ \\
\hline Xenostrobus securis & XSEC & 40 & $37.23 \pm 0.63$ & $14.73 \pm 0.13$ \\
\hline Acanthocardia echinata & $\mathrm{AECH}$ & 40 & $39.59 \pm 0.71$ & $24.52 \pm 0.14$ \\
\hline Aequipecten opercularis & AOPE & $38.62 \pm 0.73$ & $38.16 \pm 1.92$ & $14.53 \pm 0.06$ \\
\hline Chlamys varia & CVAR & 40 & $36.94 \pm 0.76$ & $13.71 \pm 0.09$ \\
\hline Limaria hians & LHIA & 40 & 40 & $16.61 \pm 0.03$ \\
\hline Pecten maximus & PMAX & 40 & $37.87 \pm 1.18$ & $14.06 \pm 0.09$ \\
\hline Callista chione & $\mathrm{CCHI}$ & 40 & $39.86 \pm 0.24$ & $16.55 \pm 0.13$ \\
\hline Cerastoderma edule & CEDU & $39.69 \pm 0.54$ & $37.20 \pm 1.21$ & $25.79 \pm 0.13$ \\
\hline Clausinela fasciata & CFAS & 40 & 40 & $14.09 \pm 0.03$ \\
\hline Dreissena polymorpha & DPOL & 40 & $38.91 \pm 1.38$ & $15.03 \pm 0.13$ \\
\hline Dosinia exoleta & DEXO & 40 & 40 & $16.84 \pm 0.24$ \\
\hline Donas trunculus & DTRU & $39.88 \pm 0.20$ & $36.12 \pm 0.83$ & $18.52 \pm 0.14$ \\
\hline Ensis ensis & EENS & 40 & 40 & $15.59 \pm 0.14$ \\
\hline Ensis siliqua & ESIL & 40 & $33.63 \pm 0.43$ & $15.74 \pm 0.11$ \\
\hline Gari depressa & GDEP & 40 & $38.65 \pm 1.58$ & $18.92 \pm 0.03$ \\
\hline Glycymeris pilosa & GPIL & $39.76 \pm 0.41$ & $36.01 \pm 1.62$ & \\
\hline Laevicardium crassum & LCRA & $39.51 \pm 0.85$ & 38.220 .44 & $26.14 \pm 0.10$ \\
\hline Ruditapes decussatus & RDEC & $39.68 \pm 0.56$ & 40 & $15.21 \pm 0.04$ \\
\hline Ruditapes philippinarum & RPHI & 40 & $38.71 \pm 2.23$ & $16.02 \pm 0.04$ \\
\hline Scrobicularia plana & SPLA & 40 & $39.54 \pm 0.79$ & $17.47 \pm 0.10$ \\
\hline Solen marginatus & SMAR & 40 & $37.45 \pm 0.43$ & $15.41 \pm 0.08$ \\
\hline Spisula solida & SSOL & 40 & 40 & $18.58 \pm 0.05$ \\
\hline Venerupis pullastra & VPUL & 40 & $38.14 \pm 1.62$ & $14.78 \pm 0.03$ \\
\hline Venerupis rhomboideus & VRHO & 40 & $39.99 \pm 0.02$ & $16.33 \pm 0.04$ \\
\hline Venerupis aurea & VAUR & 40 & 40 & $17.79 \pm 0.32$ \\
\hline Venus casina & VCAS & $36.43 \pm 0.29$ & $33.87 \pm 0.18$ & $14.43 \pm 0.03$ \\
\hline Venus gallina & VGAL & 40 & 40 & $15.81 \pm 0.04$ \\
\hline Venus verrucosa & VVER & $39.80 \pm 0.34$ & $37.71 \pm 0.16$ & $14.51 \pm 0.13$ \\
\hline
\end{tabular}

\section{Discussion}

As mentioned above, mollusc larvae are difficult to identify due to their small size and morphological similarity. Therefore, alternative techniques for their identification through morphological characteristics are required. To this end, in recent years alternative methods based on immunological and DNA techniques, FISH-SC, and image analysis have been applied. Although all of them, real time PCR included, have greatly improved larvae identification and quantification, none has been found to be entirely suitable.

Immunological techniques have been used to identify plankton larvae (Perez et al. 2009). There are, however, a number of disadvantages associated with such techniques, including the need to produce monoclonal antibodies, maintain hybridomas and the need for incubation steps, all of which results in longer analysis times. Furthermore, to obtain quality stained larvae, these have to be preserved in more restrictive 


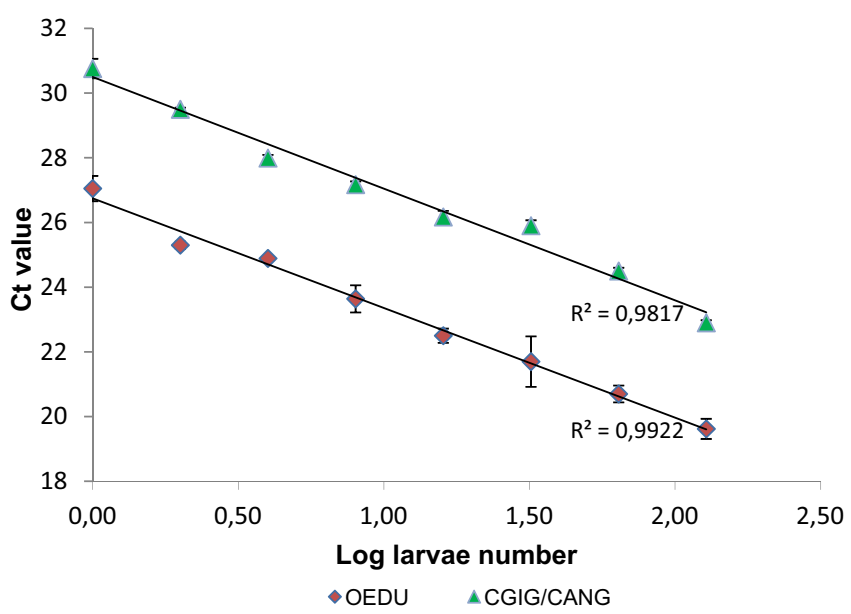

Fig. 2. Standard curve of Crassostrea gigas/C. angulata, CGIG/ ANG_16S (triangle) and Ostrea edulis, OEDU_16S (diamond) systems showing $\mathrm{Ct}$ (threshold cycle) values plotted against logarithm of larvae number (1 to 128) analyzed in triplicate.

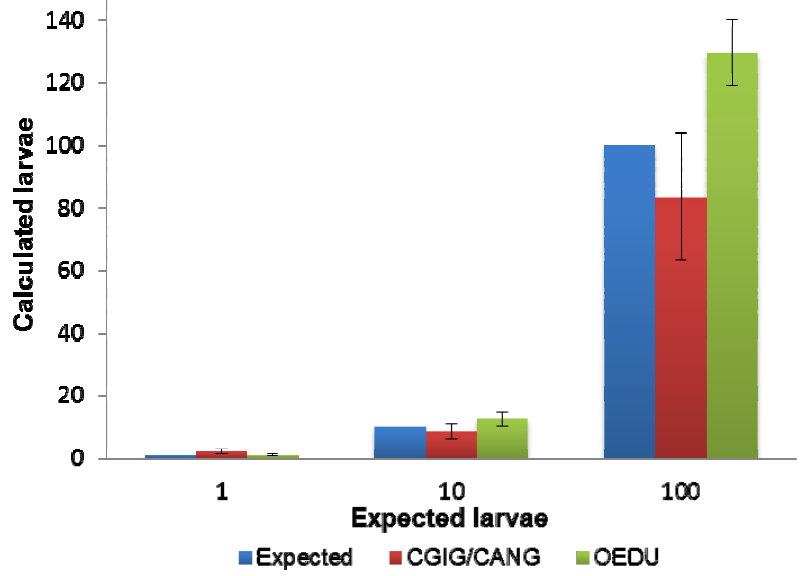

Fig. 3. Correlation between the expected and quantified skyped larvae in plankton samples.

conditions than those needed for DNA analysis. For example, ethanol cannot be used in immuno-detection as it affects the antigen and consequently the staining of the larvae (Perez et al. 2009).

Fluorescent in situ hybridization with DNA probes and image analysis (Le Goff-Vitry et al. 2007; Goodwin et al. 2014) have the drawbacks of autofluorescence and the effect of different growth conditions (temperature and salinity) on shell formation, respectively.

In this study, we have proposed a specific TaqMan real time system for identifying and quantifying oyster larvae from $C$. gigas and $O$. edulis species. The systems were designed for the $16 \mathrm{~S}$ rDNA region where intra-specific variability was either absent or very low. The developed probe and primers have been shown to be highly specific and able to differentiate the species of interest from a large number of other bivalve species. Moreover, both systems showed high sensitive: the detection of only one larva in a plankton sample was possible.
The quantification method shown here is based on the use of standards and same sized spiked larvae. One may hypothesize that larval size may affect the number of mtDNA molecules per larva, and therefore different larval sizes may produce different responses to real time PCR. However, Vadopalas et al. (2006) have shown that pinto abalone larval quantification was not affected by differences in larval size. Further studies must nevertheless be conducted in order to verify whether there is any effect on quantification results across the entire range of oyster larval sizes. If so, a new protocol that separates larvae by size should be employed to circumvent this problem.

In this work, we have demonstrated that real-time PCR facilitates identification and quantification of two of the most important commercial oyster species. This is the first time that this technique has been used for this purpose. The high correlation observed between larvae number calculated by realtime PCR assay and the real larvae number in spiked plankton samples is truly outstanding. Although real-time PCR has been shown to be a valid technique for the aims proposed in this work, the size range of the quantified larvae cannot be provided. This disadvantage could be overcome by combining the real-time PCR technique with other techniques such as image analysis.

\section{Conclusion}

Molecular technologies like real-time PCR not only facilitate species identification but also reduce bivalve larvae analysis time. The present study proposes a DNA method which is rapid, one-step, time-saving and simpler than any other DNA technique previously described, for identifying and quantifying Crassostrea gigas and Ostrea edulis larvae. This method can be a useful tool for monitoring spawning in certain areas, even in areas where $C$. gigas and $O$. edulis are mixed with closely related species, because of the high specificity and very low cross-reaction of the proven TaqMan systems. In addition, the tool could be used in ecological studies such as those concerning the influence of different parameters on larvae population dynamics.

Acknowledgements. We thank Sylvie Lapègue and Serge Heurtebise (IFREMER), Ziniu Yu (Institute of Oceanology, China), Masashi Sekino (Tohoku National Fisheries Research Institute, Japan), John Wares (University of Georgia), Jorge Toro (Southern University of Chile), David A. Stick (Oregon State University) and J. A. Fernández Barreiro and Xusto Otero González from Conselleria do Mar (Xunta de Galicia, Delegacion Comarcal, Vilagarcía) for kindly supplying us with mollusc samples. Special thanks are also due to Raquel Díez and $\mathrm{M}^{\mathrm{a}}$ Luisa Fernández (CETMAR) for supplying field plankton samples. The authors are grateful to the following fishing organizations that collaborated with sampling: "Shellfish Producers Association of Vilaboa and Arcade", and "Cambados and Cangas Fish Auction" sites. Our deepest thank to Bruno Almón and Patricia Ramos for sampling and their collaboration in the morphological identification of some samples. The technical assistance received from Susana Otero and Carlos Carballeira is much appreciated.

This study was funded by the Xunta de Galicia through project 07MMA024402PR. 


\section{Online-only materials}

Table S1. Alignment of 16S rRNA partial sequences, showing the position of the Ostrea edulis, OEDU_16S system.

Table S2. Alignment of $18 \mathrm{~S}$ rRNA partial sequences from GenBank, showing the position of bivalve, BIV_18S system.

\section{References}

André C., Lindegarth M., Jonsson P.R., Sundberg P., 1999, Species identification of bivalve larvae using random amplified polymorphic (RAPD): differentiation between Cerastoderma edule and C. lamarcki. J. Mar. Biol. Assoc. UK 79, 563-565.

Applied Biosystems, 2005, Real-Time PCR Systems. Chemistry Guide.

Bell J.L., Grassle J.P., 1998, A DNA probe for identification of larvae of the commercial surfclam (Spisula solidissima). Mol. Mar. Biol. Biotechnol. 7, 127-137.

Bendezu I.F., Slater J.W., Carney B.F., 2005, Identification of Mytilus spp. and Pecten maximus in Irish waters by standar PCR of the 18S rDNA gene and multiplex PCR of the 16S rDNA gene. Mar. Biotechnol. 7, 687-696.

Dias P.J., Sollelis L., Cook E.J., Piertney S.B., Davies I.M., Snow, M., 2008, Development a real-time PCR assay for detection of Mytilus species specific alleles: Application to a sampling survey in Scotland. J. Exp. Mar. Biol. Ecol. 367, 253-258.

Figueiras F.G., Labarta U., Fernandez-Reiriz M.J., 2002, Coastal upwelling, primary production and mussel growth in the Rias Baixas of Galicia. Hydrobiologia 484, 121-131.

Garland E.D., Zimmer C.A., 2002, Techniques for the identification of bivalve larvae. Mar. Ecol. Prog. Ser. 225, 299-310.

Goodwin J.D., North E.W., Thompson C.M., 2014, Evaluating and improving a semi-automated image analysis technique for identifying bivalve larvae. Limnol. Oceanogr. Methods 12, 548-562.

Hall T.A., 1999, BioEdit: a user-friendly biological sequence alignment editor and analysis program for windows 95/98/NT. Nucleic Acids Symp. Ser. 41, 95-98.

Hare M.P., Palumbi S.R., Butman C.A., 2000, Single-step species identification of bivalve larvae using multiplex polymerase chain reaction. Mar. Biol. 137, 953-961.

Henzler C.M., Hoaglund E.A., Gaines S.D., 2010, FISH-CS- A rapid method for counting and sorting species of marine zooplankton. Mar. Ecol. Prog. Ser. 410, 1-11.

Hosoi M., Hosoi-Tanabe S., Sawada H., Ueno M., Toyohara H., Hayashi I., 2004, Sequence and polymerase chain reactionrestriction fragment length polymorphism analysis of the large subunit rRNA gene of bivalve: Simple and widely applicable technique for multiple species identification of bivalve larva. Fish. Sci. 70, 629-637.

Hosoi-Tanabe S., Sako Y., 2005, Species-specific detection and quantification of toxic marine dinoflagellates Alexandrium tamarense and A. catenella by real-time PCR assay. Mar. Biotechnol. 7, $506-514$.

Hurwood D.A., Heasman M.P., Mather P.B., 2005, Gene flow, colonisation and demographic history of the flat oyster Ostrea angasi. Mar. Freshw. Res. 56, 1099-1106.

Iglesias D., Rodríguez L., Montes J., Conchas R.F., Pérez J.L., Fernández M., Guerra A., 2005, Estudio de viabilidad del cultivo de ostra rizada Crassostrea gigas (Thunberg, 1793) en diferentes rías gallegas. Primeros resultados biológico-productivos. Bol. Inst. Esp. Oceanogr. 21, 293-309.
Johnson M., Zaretskaya I., Raytselis Y., Merezhuk Y., McGinnis S., Madden T.L., 2008, NCBI BLAST: a better web interface. Nucleic Acid Res. 36 (Suppl. 2), W5-W9.

Jozefowicz C.J., Ó Foighil D., 1998, Phylogenetic analysis of southern hemisphere flat oysters based on partial mitochondrial 16S rDNA gene sequences. Mol. Phyl. Evol. 10, 426-435.

Kenchington E., Bird C.J., Osborne J., Reith M., 2002, Novel repeat elements in the nuclear ribosomal RNA operon of the flat oysters $O$. edulis C. Linnaeus, 1758 and $O$. angasi Sowerby, 1871. J. Shellfish Res. 21, 697-705.

Le Goff-Vitry M.C., Chipman A.R., Comtet T., 2007, In situ hybridization on whole larvae: a novel method for monitoring bivalve larvae. Mar. Ecol. Prog. Ser. 343, 161-172.

Lorenzo-Abalde S., González-Fernández A., De Miguel Villegas E., Fuentes J., 2005, Two monoclonal antibodies for the recognition of Mytilus spp. larvae: Studies on cultured larvae and tests on plankton samples. Aquaculture 250, 736-747.

Mirella da Silva P., Fuentes J., Villalba A., 2005, Growth, mortality and disease susceptibility of oyster Ostrea edulis families obtained from brood stocks of different geographical origins, through on-growing in the Ria de Arousa (Galicia, NW Spain). Mar. Biol. 147, 965-977.

Palumbi S.R., Martin A., Romano S., McMillan W.O., Stice L., Grabowski G., 1991, The simple Fool's Guide to PCR. Department of Zoology, University of Hawaii, Honolulu.

Pan M., McBeath A.J.A., Hay S.J., Pierce G.J., Cunningham C.O., 2008, Real-time PCR assay for detection and relative quantification of Liocarcinus depurator larvae from plankton samples. Mar. Biol. 153, 859-870.

Patil J.G., Gunasekera R.M., Deagle B.E., Bax N.J., 2005, Specific detection of Pacific oyster (Crassostrea gigas) larvae in plankton samples using nested polymerase chain reaction. Mar. Biotech. 7, $11-20$.

Paugam A., Le Pennec M., Geneviéve A.F., 2000, Immunological recognition of marine bivalve larvae from plankton samples. J. Shellfish Res. 19, 325-331.

Paugam A., Le Pennec M., Marhic A., Geneviéve A.F., 2003, Immunological in situ determination of Pecten maximus larvae and their temporal distribution. J. Mar. Biol. Assoc. UK 83, 1083-1093.

Pérez D., Lorenzo-Abalde S., González-Fernández A., Fuentes J., 2009, Immunodetection of Mytilus galloprovincialis larvae using monoclonal antibodies to monitor larval abundance on the Galician coast: Optimization of the method and comparison with identification by morphological traits. Aquaculture 294, 86-92.

Quinteiro J., Pérez-Diéguez L., Sánchez A., Pérez-Martín R.I., Sotelo C.G, Rey-Méndez M., 2011, Quantification of manila clam Ruditapes philippinarum (Adams \& Reeve, 1850) larvae based on SYBR Green real-time polymerase chain reaction. J. Shellfish Res. 30, 791-796.

Reece K.S., Cordes J.F., Stubbs J.B., Hudson K.L., Francis E.A., 2008, Molecular phylogenies help resolve taxonomic confusion with Asian Crassostrea oyster species. Mar. Biol. 153, 709-721.

Smith K.F., Wood S.A., Mountfort D.O., Cary S.C., 2012, Development of a real-time PCR assay for the detection of the invasive clam, Corbula amurensis, in environmental samples. J. Exp. Mar. Biol. Ecol. 412, 52-57.

Thompson J.D., Gibson T.J., Plewniak F., Jeanmougin F., Higgins D.G., 1997, The CLUSTAL X windows interface: Flexible strategies for multiple sequence alignment aided by quality analysis tools. Nucleic Acids. Res. 25, 4876-4882. 
Thompson C.M., Hare M.P., Gallager S.M., 2012, Semi-automated image analysis for the identification of bivalve larvae from a Cape Cod estuary. Limnol. Oceanogr. Methods 10, 538-554.

Toro J.E., 1998, Molecular identification of four species of mussels from southern Chile by PCR-based nuclear markers: The potential use in studies involving planktonic surveys. J. Shellfish Res. 17, 1203-1205.

Vadopalas B., Bouma J.V., Jackels C.R., Friedman C.S., 2006, Application of real-time PCR for simultaneous identification and quantification of larval abalone. J. Exp. Mar. Biol. Ecol. 334, 219-228.
Wang S., Bao Z., Zhang L., Li N., Zhan A., Guo W., Wang X., Hu J., 2006, A new strategy for species identification of planktonic larvae: PCR-RFLP analysis of the internal transcribed spacer region of ribosomal DNA detected by agarose gel electrophoresis or DHPLC. J. Plankton Res. 28, 375-384.

Wight N.A., Suzuki J., Vadopalas B., Friedman C.S., 2009, Development and optimization of quantitative PCR assays to aid Ostrea lurida carpenter 1864 restoration efforts. J. Shellfish Res. 28, 33-41.

Yuan J.S., Reed A., Chen F., Stewart Jr. C.N., 2006, Statistical analysis of real-time PCR data. BMC Bioinformatics 7. 


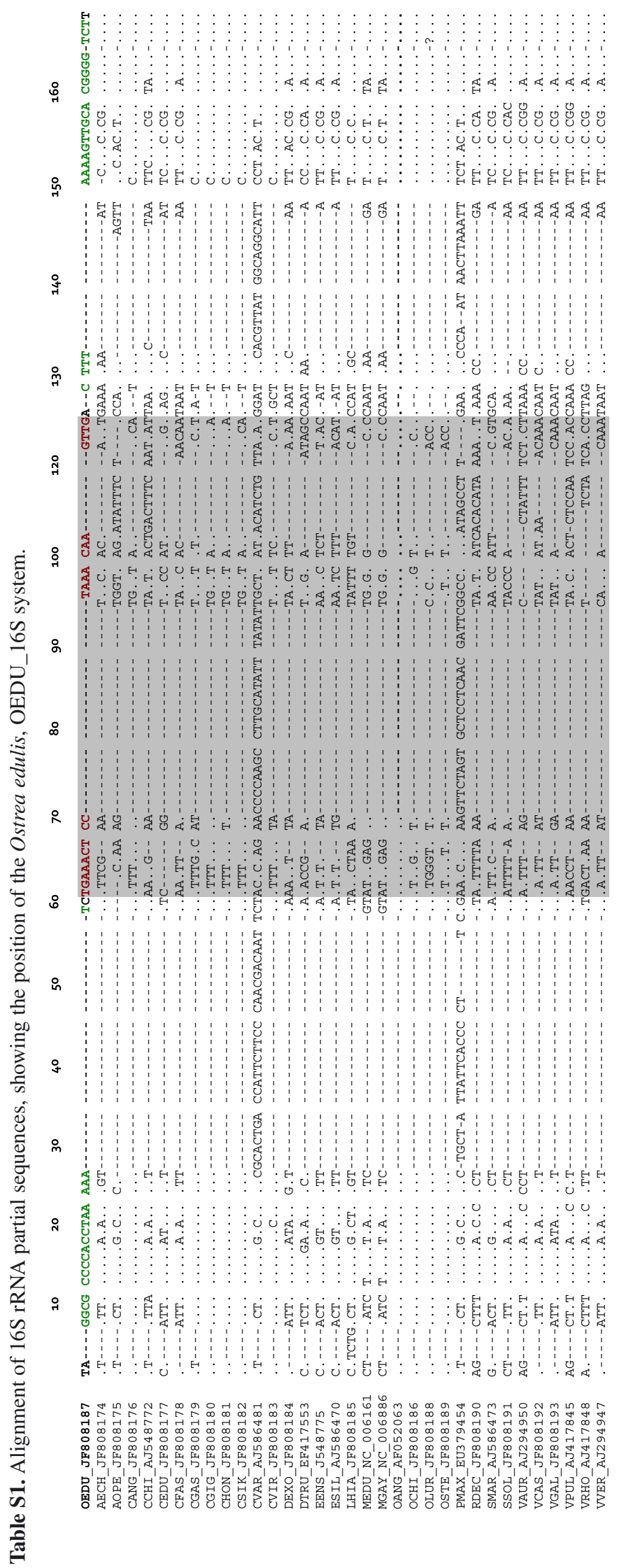




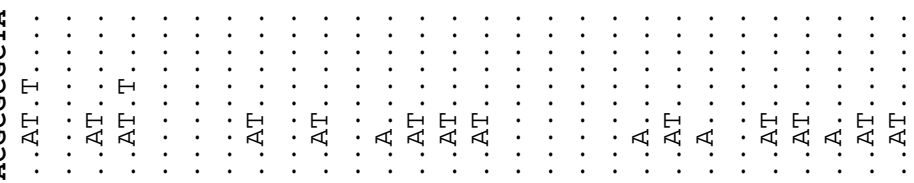

잉
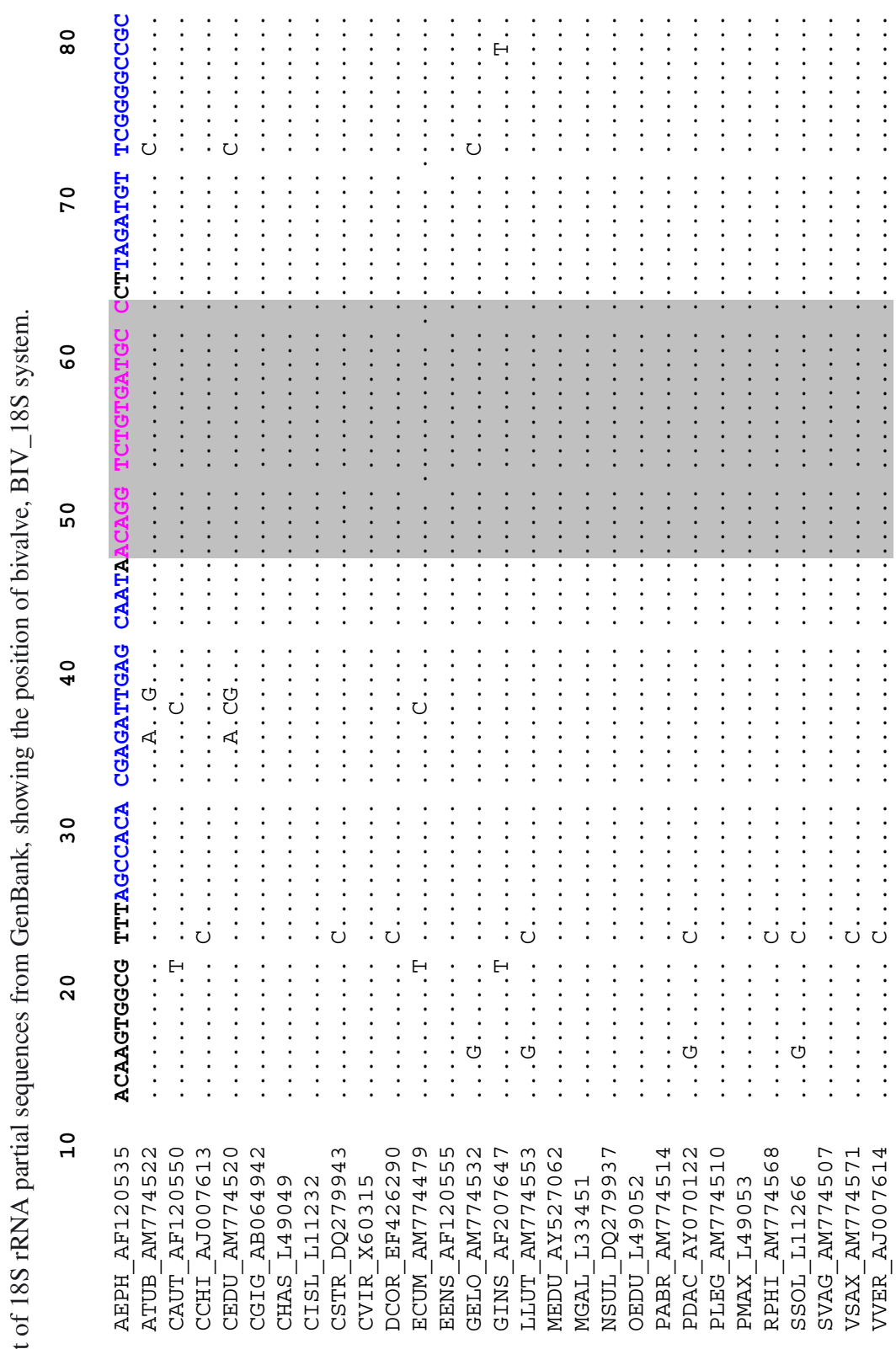